\section{Effect of Composted Biosolids on Soil Organic Carbon Storage During Establishment of Transplanted Sod}

\author{
Xiaoyan Dai \\ Texas Railroad Commission, 1701 North Congress, Austin, TX 78711-2967
}

Donald M. Vietor ${ }^{1}$, Frank M. Hons, Tony L. Provin,
and Richard H. White
Department of Soil and Crop Sciences, Texas A\&M University, 2474 TAMU,
College Station, TX 77843-2474

Thomas W. Boutton

Department of Ecosystem Science \& Management, Texas A\&M University, College Station, TX 77843

\section{Clyde L. Munster \\ Biological and Agricultural Engineering Department, Texas A\&M University, College Station, TX 77843-2138}

Additional index words. turfgrass, composted biosolid, dissolved organic carbon, soil organic carbon

\begin{abstract}
Large, volume-based applications of composted municipal biosolids (CMB) can enhance turfgrass growth and quality and soil physical and chemical properties. In addition, CMB additions could affect short-term dynamics of soil organic carbon (SOC) and enhance $C$ sequestration and environmental quality compared with turfgrass fertilized with inorganic nutrients in mineral soil. The objective was to compare changes in SOC among contrasting sources of Tifway bermudagrass sod (Cynodon dactylon L. Pers. $\times C$. transvaalensis Burtt-Davey) after transplanting. Three sod sources from fields grown with two commercial sources of CMB or inorganic phosphorus fertilizer were transplanted on silica sand in replicated box lysimeters. Storage of SOC within 0 to 5-cm and 5 to 50-cm depths was greater in CMB than fertilizer-grown sod during 10 months of establishment and maintenance. Leaching losses of dissolved organic C (DOC) were two times greater for $\mathrm{CMB}$ than for fertilizer-grown sod over seven simulated rain events, but the ratio of DOC in leachate to total SOC mass was $0.3 \%$ or less for CMBgrown sod. An increase in $\delta^{13} \mathrm{C}$ values of SOC over sampling dates indicated the proportion of SOC derived from turfgrass increased, whereas that from CMB decreased. The benefit of greater rates of SOC storage during establishment and maintenance of CMB compared with fertilizer-grown sod was achieved without substantive loss of DOC in leachate.
\end{abstract}

Top-dressings of composted municipal biosolids (CMB) increase nutrient concentrations in soil and clippings and enhance turfgrass color, quality, and growth (Garling and Boehm, 2001; Hansen et al., 2007; Johnson et al., 2005). In addition, incorporation of large, volume-based rates of $\mathrm{CMB}$ amendments reduce soil bulk density, sod weight, and the portion of native soil removed in sod harvests (Vietor et al., 2007). Moreover, the volume-based rates of CMB, which are recommended for remediation of low-quality soils on urban landscapes, contribute to increased concentrations of soil

Received for publication 30 Oct. 2008. Accepted for publication 19 Dec. 2008.

We acknowledge financial support of the USDA SARE of the Southern Region; the Texas Turfgrass Research, Education, and Extension Endowment; and Texas AgriLife Research.

${ }^{1}$ To whom reprint requests should be addressed; e-mail dvietor@tamu.edu. short-term C storage. Over the long term (50 years), CENTURY model simulations indicated turfgrass systems were a potential $\mathrm{C}$ sink in western Colorado without CMB amendments (Bandaranayake et al., 2003).

The apparent benefits of $\mathrm{CMB}$ must be weighed against potential negative environmental impacts, including runoff and leaching of nutrients (Hansen et al., 2007; Hay et al., 2007). For example, increased SOC can contribute to increased dissolved organic C (DOC) concentration and greater solubility and movement of zinc and other nutrients in soil (Royer et al., 2007; Wright et al., 2005). The decomposition of SOC contributes to increases in soil DOC, but deposition and decay of turfgrass clippings and biomass are other potential DOC sources.

Although not quantified in previous studies of compost-amended turfgrass (Wright et al., 2005), methods are available for evaluating effects of $\mathrm{CMB}$ and turfgrass sources of organic matter on SOC dynamics. Variation of the natural abundance of stable $\mathrm{C}$ isotopes $\left({ }^{13} \mathrm{C} /{ }^{12} \mathrm{C}\right)$, measured in relation to a reference value as $\delta^{13} \mathrm{C}$, can be used to quantify sources and turnover of SOC (Boutton, 1996). The $\delta^{13} \mathrm{C}$ values of plants with the $C_{3}$ photosynthetic pathway are relatively low compared with those of plants with the $\mathrm{C}_{4}$ pathway. The $\delta^{13} \mathrm{C}$ values of $\mathrm{CMB}$ used in this study were relatively low and similar to values observed in tissues of $\mathrm{C}_{3}$ plants $(-25 \%$ to $-27 \%$ oo. In contrast, the $\delta^{13} \mathrm{C}$ values of clippings of Tifway bermudagrass, a $\mathrm{C}_{4}$ turfgrass, were relatively high $(-13 \%$ to $15 \%$ ). The contrasting $\delta^{13} \mathrm{C}$ values of $\mathrm{CMB}$ and bermudagrass provided a unique opportunity for evaluating short-term changes of SOC in turfgrass sod amended with CMB The objectives of this study were to: 1) compare SOC storage between $\mathrm{CMB}$ and fertilizer-grown sod after transplanting; 2) monitor changes in SOC storage over time; and 3 ) use $\delta^{13} \mathrm{C}$ values of SOC to evaluate $\mathrm{C}$ sources and dynamics during establishment of transplanted sod.

\section{Materials and Methods}

carbon (SOC) within amended depths (Hansen et al., 2007; Vietor et al., 2007; Wright et al., 2005). Increased SOC enhances water infiltration and soil water retention compared with soil without $\mathrm{CMB}$ during production and after transplanting of sod (Boyle et al., 1989; Johnson et al., 2006).

Organic $\mathrm{C}$ applied as CMB or CMBamended sod could contribute to greater short- and long-term $\mathrm{C}$ storage in urban soils than organic $\mathrm{C}$ from clippings and sod transplanted from turfgrass grown with inorganic fertilizers (Pouyat et al., 2006). Short-term storage of large amounts of organic $\mathrm{C}$ was documented previously for volume-based $\mathrm{CMB}$ rates on turf. Concentrations of SOC increased as $\mathrm{CMB}$ rates increased from 0 to $160 \mathrm{mg} \cdot \mathrm{ha}^{-1}$, but SOC remained relatively constant for each rate over a period of 10 months after CMB application (Wright et al., 2005). In addition to the added CMB, turfgrass clippings and decaying biomass below the clipping height could have contributed to
Experimental design. A randomized complete block design comprised four replications of three different sources of Tifway bermudagrass sod that were transplanted on 12 box lysimeters $\left(2.25 \mathrm{~m}^{2} \times 0.5-\mathrm{m}\right.$ depth $)$ during Aug. 2004. Lysimeters were located outdoors on the Texas AgriLife Research Farm in Burleson County. Mean monthly maximum temperature at the lysimeter site ranged from 16 to $33{ }^{\circ} \mathrm{C}$ and mean monthly minimum temperature from 4.3 to $20{ }^{\circ} \mathrm{C}$. Mean maximum relative humidity was $100 \%$ and mean minimum relative humidity was $66 \%$. A translucent fiberglass roof excluded natural rainfall from lysimeters but allowed a photosynthetic photon flux $(P P F)$ of 650 $\mu \mathrm{mol} \cdot \mathrm{m}^{-2} \cdot \mathrm{s}^{-1}$ during midday on lysimeter surfaces. The design of the lysimeter facility was described previously (Hay et al., 2007). Briefly, a 5-cm diameter polyvinyl chloride well screen pipe was placed at the bottom of 
lysimeters for leachate sampling and covered with $50 \mathrm{~cm}$ of packed silica sand (diameter of $98 \%$ of particles greater than $50 \mu \mathrm{m}$ ) before sod was transplanted. Water for irrigation and simulated rain was pumped from a groundwater source and applied through four square-pattern nozzles on each lysimeter. Each nozzle delivered $5.3 \mathrm{~L} / \mathrm{min}$ at 0.14 MPa (20 psi) (Spraying Systems Co., Wheaton, IL). After an initial irrigation and collection of leachate from the sand medium, sod was transplanted and lysimeters were irrigated daily during September and on alternate days from Oct. 2004 through July 2005 to balance evapotranspiration. Fertilizer nitrogen $\left(50 \mathrm{~kg} \cdot \mathrm{ha}^{-1} \mathrm{~N}\right)$ was applied to transplanted sod in lysimeters during Oct. 2004 and April and June 2005.

Sod management and sampling before transplanting. The three sources of sod transplanted on lysimeters were harvested to a 2.5$\mathrm{cm}$ depth from Tifway turf grown with and without volume-based rates (1.2-cm depth) of either of two CMB sources as described previously (Hansen et al., 2007). The Dillo Dirt source was from Austin and the other CMB source was from Bryan, TX. Both sources were a blend of biosolids from wastewater treatment and ground yard trimmings (Table 1). Each CMB source was topdressed after sprigging of Tifway in Spring 2004 on an exposed $\mathrm{E}_{\mathrm{g}}$ horizon of a truncated Boonville soil (fine, smectitic, thermic Ruptic-vertic Albaqualf). In addition, Tifway grown with inorganic fertilizer only provided a control. A modified Kjeldahl method was used to digest dry soil and CMB samples for total nutrient analyses before Tifway was sprigged and CMB was top-dressed (Hansen et al., 2007). Total $\mathrm{N}$ concentration in digests of soil and CMB were measured colorimetrically and inductively coupled plasma optical emission spectroscopy (ICP) was used to measure total phosphorus $(\mathrm{P})$ or potassium (K) concentration (Table 1).

Total soil nutrient concentrations before sprigging and application of CMB or fertilizer were $200 \mathrm{mg} \cdot \mathrm{kg}^{-1}$ for $\mathrm{N}, 52 \mathrm{mg} \cdot \mathrm{kg}^{-1}$ for $\mathrm{P}$, and $633 \mathrm{mg} \cdot \mathrm{kg}^{-1}$ for $\mathrm{K}$. The volumes of $\mathrm{CMB}$ applied to replicated plots were weighed and subsamples were dried and analyzed as described previously for computing total $\mathrm{N}, \mathrm{P}$, and $\mathrm{K}$ rates. The rates applied as $\mathrm{CMB}$ were $1097 \mathrm{~kg} \cdot \mathrm{ha}^{-1}$ of total N, $575 \mathrm{~kg} \cdot \mathrm{ha}^{-1}$ of total $\mathrm{P}$, and $418 \mathrm{~kg} \cdot \mathrm{ha}^{-1}$ of total $\mathrm{K}$ for Dillo Dirt and were $722 \mathrm{~kg} \cdot \mathrm{ha}^{-1}$ of total N, $316 \mathrm{~kg} \cdot \mathrm{ha}^{-1}$ of total $\mathrm{P}$, and $180 \mathrm{~kg} \cdot \mathrm{ha}^{-1}$ of total $\mathrm{K}$ for Bryan compost. The fertilizer-grown sod received $50 \mathrm{~kg} \cdot \mathrm{ha}^{-1}$ of $\mathrm{P}(0-46-0)$ before sprigging as described for a previous study (Hansen et al., 2007). In addition, inorganic

$\mathrm{N}\left[\left(\mathrm{NH}_{4}\right)_{2} \mathrm{SO}_{4}\right]$ was applied to the $\mathrm{CMB}$ and fertilizer-grown treatments at rates of $50 \mathrm{~kg} \cdot \mathrm{ha}^{-1} \mathrm{~N}$ on 15 and 24 June; 2, 13, and 23 July; and 16 Aug. 2004 to promote rapid turf coverage before sod was harvested and transplanted to lysimeters.

Sampling and analysis of leachate, turfgrass, and soil. After the CMB and fertilizergrown sods were transplanted on box lysimeters in Aug. 2004, a 4-cm depth of simulated rain was applied on seven dates at 15- to 45d intervals throughout the study to achieve matrix flow of water through the sand medium to leachate samplers. Leachate volumes were pumped from the pipe samplers after each simulated rain event, measured, subsampled, and filtered $(0.45 \mu \mathrm{m}$ or less $)$ for analysis of DOC.

Turf was clipped to a 5 -cm height when leaves reached $12.5 \mathrm{~cm}$ during establishment of transplanted sod in fall and regrowth in spring. Clippings were weighed and sampled and samples were dried at $60{ }^{\circ} \mathrm{C}$. Dried samples were weighed and composited over mowing dates preceding each of three soil sampling dates (described subsequently) before grinding and analysis of total organic $\mathrm{C}$ and $\delta^{13} \mathrm{C}$ values. Wet clippings were returned to lysimeter surfaces after sampling during March through June 2005 to include contributions of total spring and summer turfgrass biomass in evaluations of SOC storage.

Three soil cores (3.2-cm diameter) were sampled to the $50-\mathrm{cm}$ depth in each lysimeter during Oct. 2004 and March and July 2005. The three cores were divided into four depths ( 0 to $5 \mathrm{~cm}, 5$ to $15 \mathrm{~cm}, 15$ to $30 \mathrm{~cm}$, and 30 to $50 \mathrm{~cm}$ ). Two additional cores were sampled to the $0-$ to $5-\mathrm{cm}$ depth only. Sampling to the 0 - to $5-\mathrm{cm}$ depth enabled recovery of soil introduced with transplanted sod, including colloidal particles transported into the pore space of silica sand immediately below sod. The cores were pooled within the respective depths of sampling for each lysimeter. The composite sample from each depth increment was weighed and subsampled for drying at $105{ }^{\circ} \mathrm{C}$ to determine water content and bulk density. The remainder of the sample from each depth was dried at $60{ }^{\circ} \mathrm{C}$ for $48 \mathrm{~h}$ and passed through a 2-mm sieve to remove plant fragments of turfgrass and of yard waste applied with compost. Sieved samples were homogenized thoroughly and pulverized in a centrifugal mill before elemental and isotopic analyses of carbon. Total N, P, and $\mathrm{K}$ in soil sampled from the 0 - to $5-\mathrm{cm}$ depth in July 2005 were analyzed as described previously for $\mathrm{CMB}$ and soil during the sod production phase (Hansen et al., 2007). In addition,

Table 1. Concentrations of total nitrogen $(\mathrm{N})$, phosphorus $(\mathrm{P})$, organic carbon $(\mathrm{C})$, dissolved organic $\mathrm{C}$ (DOC), and dry matter and $\delta^{13} \mathrm{C}$ values for sources of composted biosolids and Tifway bermudagrass clippings.

\begin{tabular}{|c|c|c|c|c|c|c|}
\hline C source & $\mathrm{C}$ & $\mathrm{N}$ & $\begin{array}{c}\mathrm{P} \\
-\end{array}$ & DOC & $\begin{array}{c}\text { Dry matter } \\
\left(\mathrm{mg} \cdot \mathrm{g}^{-1}\right)\end{array}$ & $\begin{array}{l}\delta^{13} \mathrm{C} \\
(\%)\end{array}$ \\
\hline Bryan compost & 193 & 14.5 & 5.80 & 2.80 & 550 & -25.9 \\
\hline Dillo Dirt compost & 254 & 20.7 & 9.55 & 2.23 & 480 & -26.9 \\
\hline Turfgrass clippings & 433 & 27.4 & 2.76 & - & 440 & -13.9 \\
\hline
\end{tabular}

nitrate- $\mathrm{N}$ and soil-test $\mathrm{P}$ and $\mathrm{K}$ in the same samples were extracted and measured. The nitrate- $\mathrm{N}$ was extracted as described by Keeney and Nelson (1982) and measured through cadmium reduction (Dorich and Nelson, 1984). The ICP was used to measure $\mathrm{P}$ and $\mathrm{K}$ in Mehlich 3 extracts of soil.

Organic carbon and $\delta^{13} \mathrm{C}$ analysis. An OI Analytical Model 700 total organic $\mathrm{C}$ analyzer (O-I-Analytical, College Station, TX) was used to quantify DOC in leachate. A Carlo Erba EA-1108 interfaced with a Delta Plus isotope ratio mass spectrometer (ThermoFinnigan, San Jose, CA) operating in continuous flow mode was used to quantify SOC and $\delta^{13} \mathrm{C}$ values of SOC and organic C in clipping samples. All stable isotope analyses were reported relative to the international V-PDB standard calibrated through NBS-19 (Coplen, 1995; Hut, 1987). Precision was less than $0.1 \%$ for $\delta^{13} \mathrm{C}$. A mass balance equation was used to estimate the fraction of SOC derived from $\mathrm{C}_{4}$ sources within the 0 - to 5-cm soil depth $\left(\mathrm{F}_{\mathrm{C} 4}\right)$ :

$$
\mathrm{F}_{\mathrm{C} 4}=\left[\left(\delta_{\text {sample }}-\delta_{\mathrm{C} 3}\right) /\left(\delta_{\mathrm{C} 4}-\delta_{\mathrm{C} 3}\right)\right]^{*} 100
$$

where $\delta_{\text {sample }}$ is the $\delta^{13} \mathrm{C}$ value of the whole soil organic matter, $\delta_{\mathrm{C} 3}$ is the $\delta^{13} \mathrm{C}$ values of the $\mathrm{C}_{3}$ components (two sources of $\mathrm{CMB}$ ), and $\delta_{\mathrm{C} 4}$ is the average $\delta^{13} \mathrm{C}$ value of the $\mathrm{C}_{4}$ plant components (bermudagrass) (Bernoux et al., 1998; Boutton et al., 1999; Leavitt et al., 1994).

Statistical analysis. Analysis of variance (SAS Institute Inc., 2000) was used to compare SOC, total and soil-test nutrient concentrations, $\delta^{13} \mathrm{C}$ values in soil, and $\mathrm{DOC}$ in leachate among sod sources or sampling dates. When interactions between sod sources and sampling dates were significant $(P<$ $0.05)$, sampling dates were analyzed separately. Fisher's least significant difference test was used to compare means of sod sources or sampling dates $(P<0.05)$.

\section{Results and Discussion}

Fate of organic carbon. The total organic $\mathrm{C}$ imported with transplanted sod at the start of the experiment was greater $(P<0.05)$ for CMB than fertilizer-grown sod (Table 2). Although the contribution of CMB to SOC was not statistically different between the amended sod sources, the higher mean organic C concentration in Dillo Dirt (Table 1) was reflected in the greater organic $C$ imports with sod grown with Dillo Dirt (Table 2). The mean SOC mass within the 0 - to 5-cm depth increased on March and July sampling dates, remained greater $(P<0.05)$ for both CMB-amended sod treatments than for fertilizer-grown sod, and was at least $18 \%$ greater for sod with Dillo Dirt than sod with Bryan compost. Greater SOC within the surface layer for $\mathrm{CMB}$ than fertilizer-grown sod was consistent with a report of greater short-term $\mathrm{C}$ sequestration in soil amended with sewage sludge rather than inorganic fertilizer during corn (Zea mays L.) production (Fernandes et al., 2005). 
Table 2. Mass balance of soil organic carbon (SOC) of sod transplanted to box lysimeters from turfgrass top-dressed with Dillo Dirt, Bryan compost, and inorganic phosphorus (P) fertilizer.

\begin{tabular}{|c|c|c|c|}
\hline Mass balance of SOC & Bryan compost & Dillo Dirt & Fertilizer $\mathrm{P}$ \\
\hline \multicolumn{4}{|l|}{ Oct. 2004} \\
\hline Imports in sod, 0 to $2.5 \mathrm{~cm}\left(\mathrm{~g} \cdot \mathrm{m}^{-2}\right)$ & $493 a^{2}$ & $713 \mathrm{a}$ & $58 \mathrm{~b}$ \\
\hline Imports in sand, 0 to $50 \mathrm{~cm}\left(\mathrm{~g} \cdot \mathrm{m}^{-2}\right)$ & 141 & 141 & 141 \\
\hline $\mathrm{SOC}, 0$ to $5 \mathrm{~cm}\left(\mathrm{~g} \cdot \mathrm{m}^{-2}\right)$ & $670 \mathrm{a}$ & $623 \mathrm{a}$ & $152 \mathrm{~b}$ \\
\hline $\mathrm{SOC} 5$ to $50 \mathrm{~cm}\left(\mathrm{~g} \cdot \mathrm{m}^{-2}\right)$ & $178 \mathrm{ab}$ & $214 \mathrm{a}$ & $126 \mathrm{~b}$ \\
\hline Leaching loss of DOC $\left(\mathrm{g} \cdot \mathrm{m}^{-2}\right)$ & $2.9 \mathrm{a}$ & $1.9 \mathrm{a}$ & $1.1 \mathrm{~b}$ \\
\hline Leachate DOC/SOC (\%) & 0.3 & 0.2 & 0.4 \\
\hline Export through clippings $\left(\mathrm{g} \mathrm{m}^{-2}\right)$ & $82 \mathrm{a}$ & $78 \mathrm{a}$ & $91 \mathrm{a}$ \\
\hline \multicolumn{4}{|l|}{ Mar. 2005} \\
\hline $\mathrm{SOC} 0$ to $5 \mathrm{~cm}\left(\mathrm{~g} \cdot \mathrm{m}^{-2}\right)$ & $933 \mathrm{a}$ & $1,104 \mathrm{a}$ & $247 \mathrm{~b}$ \\
\hline $\mathrm{SOC} 5$ to $50 \mathrm{~cm}\left(\mathrm{~g} \cdot \mathrm{m}^{-2}\right)$ & $201 \mathrm{ab}$ & $249 \mathrm{a}$ & $144 \mathrm{~b}$ \\
\hline Leaching loss of DOC $\left(\mathrm{g} \cdot \mathrm{m}^{-2}\right)$ & $3.4 \mathrm{a}$ & $3.6 \mathrm{a}$ & $1.8 \mathrm{~b}$ \\
\hline Leachate DOC/SOC (\%) & 0.3 & 0.3 & 0.5 \\
\hline Export through clippings $\left(\mathrm{g} \cdot \mathrm{m}^{12}\right)$ & 0 & 0 & 0 \\
\hline \multicolumn{4}{|l|}{ July 2005} \\
\hline SOC 0 to $5 \mathrm{~cm}\left(\mathrm{~g} \cdot \mathrm{m}^{-2}\right)$ & $1,129 \mathrm{a}$ & $1,355 \mathrm{a}$ & $310 \mathrm{~b}$ \\
\hline SOC 5 to $50 \mathrm{~cm}\left(\mathrm{~g} \cdot \mathrm{m}^{-2}\right)$ & $282 \mathrm{ab}$ & $336 \mathrm{a}$ & $209 \mathrm{~b}$ \\
\hline Leaching loss of DOC $\left(\mathrm{g} \cdot \mathrm{m}^{-2}\right)$ & $3.4 \mathrm{a}$ & $3.1 \mathrm{a}$ & $1.2 \mathrm{~b}$ \\
\hline Leachate DOC/SOC (\%) & 0.2 & 0.2 & 0.2 \\
\hline Clipping return $\left(\mathrm{g} \cdot \mathrm{m}^{-2}\right)$ & $56 \mathrm{a}$ & $68 \mathrm{a}$ & $73 \mathrm{a}$ \\
\hline
\end{tabular}

${ }^{2}$ Means followed by the same lower case letter within rows are not significantly different $(P=0.05)$ for each sampling date.

$\mathrm{DOC}=$ dissolved organic carbon

Summed over the 5- to $50-\mathrm{cm}$ depth within lysimeters, SOC was greater for sod amended with Dillo Dirt than fertilizer-grown sod $(P<0.01)$ (Table 2). In addition, the higher mean SOC recovery below $5 \mathrm{~cm}$ on each date for sod grown with Dillo Dirt reflected the higher mean organic $\mathrm{C}$ concentration in Dillo Dirt than in Bryan compost (Tables 1 and 2). Compared with fertilizergrown sod, greater SOC at depths below $5 \mathrm{~cm}$ for sod transplanted with Dillo Dirt could be attributed, in part, to leaching of soluble organic $\mathrm{C}$ in percolate from simulated rain. Recovery of SOC within the $5-$ to $50-\mathrm{cm}$ depth below CMB-amended sod was comparable to the DOC content previously reported for a $15-\mathrm{cm}$ depth of turfgrass soil amended with $120 \mathrm{mg} \cdot \mathrm{ha}^{-1} \mathrm{CMB}$ (Wright et al., 2005). Although DOC from CMB-amended sod was a potential SOC source below $5 \mathrm{~cm}$, $0.5 \%$ or less of SOC was recovered as DOC in leachate from the entire soil depth (0 to $50 \mathrm{~cm}$ ) (Table 2). Additional research is needed to evaluate the form and origin of $\mathrm{SOC}$ recovered in soil beneath CMB-amended sod.

Mean leaching loss of DOC was low, but variation did reflect the greater amounts of SOC within the $0-$ to $5-\mathrm{cm}$ depth of lysimeters for $\mathrm{CMB}$ compared with fertilizergrown sod (Table 2). Leaching loss of DOC was two times greater for CMB-grown sod than fertilizer-grown sod when totaled over simulated rain events preceding each soil sampling date. A positive correlation between SOC and DOC concentrations in soil amended with increasing $\mathrm{CMB}$ rates was observed previously during establishment and maintenance of bermudagrass turf (Wright et al., 2005). Increases of DOC soon after application of manure or other organic amendments have been attributed to soluble materials in amendments (Chantigny, 2003). Yet, rapid decomposition of the soluble organic $\mathrm{C}$ compounds can return soil DOC concentra- tions to background levels. In the present study, decomposition during the months between CMB top-dressing on newly sprigged turf and transplanting of the resulting sod harvest could have limited soil DOC concentration and leaching loss from the transplanted sod layer. The leaching loss of DOC from $\mathrm{CMB}$ and fertilizer-grown sod was comparable to relatively low DOC losses reported previously for prairie and $\mathrm{N}$-fertilized grassland on lysimeter plots and field sites (Brye et al., 2001; Chantigny, 2003).

The percentage of SOC recovered as DOC in leachate was small and similar among sod sources for each of the sampling periods (Table 2). In contrast to the previous report of a seasonal low in SOC and DOC during a November sampling after turf establishment (Wright et al., 2005), SOC mass within the 0to 5-cm depth increased between October and March sampling dates in the present study. Only one simulated rain event was applied during November through February in the present study, which could have limited leaching loss of DOC compared with a previous field study of turf under both irrigation and cool-season rainfall (Wright et al., 2005).

Clippings were a much larger component of SOC balance than DOC in leachate, but potential contributions to SOC storage were less than the organic $\mathrm{C}$ imported with CMBgrown sod on lysimeters. The organic $\mathrm{C}$ in Tifway clippings during the intervals preceding each soil sampling date was less than $18 \%$ of the SOC mass within depths to $50 \mathrm{~cm}$ for fertilizer-grown sod. For CMB-grown sods, the organic $\mathrm{C}$ in clippings was $7.2 \%$ or less of total SOC mass. Yet, the increase in SOC over the relatively short duration of this experiment revealed the substantial contribution of turfgrass $\mathrm{C}$ to $\mathrm{SOC}$ with or without return of clippings (Table 2).

Estimate of turfgrass contributions to soil organic carbon. The $\delta^{13} \mathrm{C}$ values of the two sources of $\mathrm{CMB}$ and turfgrass clippings were determined before sod was transplanted (Table 1). Values for both CMB sources were low and comparable to that of $\mathrm{C}_{3}$ plant species, which contrasted with the higher $\delta^{13} \mathrm{C}$ values of clippings of Tifway bermudagrass, a $\mathrm{C}_{4}$ plant species (Boutton, 1996). Similar to the CMB sources top-dressed during sod production and before transplanting to lysimeters, the $\delta^{13} \mathrm{C}$ values of SOC within the 0 - to 5-cm depth of CMB-grown sod were low and typical of $\mathrm{C}_{3}$ plant species over the three sampling dates (Fig. 1; Table $1)$. In contrast, $\delta^{13} \mathrm{C}$ values of SOC within the surface layer of Tifway bermudagrass sod grown with inorganic fertilizer were typical of $\mathrm{C}_{4}$ plant species (Fig. 1; Table 1).

The contrasting $\delta^{13} \mathrm{C}$ values between $\mathrm{CMB}$ and bermudagrass were reflected in estimates of the portion of SOC derived from these two $\mathrm{C}$ sources. Tifway bermudagrass was the principal source of SOC during production and after transplanting of the fertilizer-grown sod. The $\delta^{13} \mathrm{C}$ values and the percentage of SOC derived from Tifway bermudagrass within the $0-$ to $5-\mathrm{cm}$ depth were consistently greater $(P<0.001)$ for fertilizer than for CMB-grown sods (Fig. 1).

Dillo Dirt provided a major portion of SOC within the $0-$ to $5-\mathrm{cm}$ depth in one sod source, but increasing (less negative) $\delta^{13} \mathrm{C}$ values of SOC over sampling dates indicated turfgrass contributed an increasing proportion $(P<0.001)$ of SOC (Fig. 1). In addition to increasing $\mathrm{SOC}$ within the surface layer at transplanting, both CMB-grown sods increased turfgrass contributions to SOC compared with fertilizer-grown sod over the three sampling dates (Table 2). Compared with fertilizer-grown sod, the increase in SOC storage was two times greater for sod grown with Bryan $\mathrm{CMB}$ and three times greater with Dillo Dirt 10 months after transplanting.

The percentage of SOC attributed to Tifway bermudagrass increased after transplanting on lysimeters for all three sod sources from Oct. 2004 to Mar. $2005(P<0.05)$ and from Oct. 2004 to July $2005(P<0.01)$ (Table

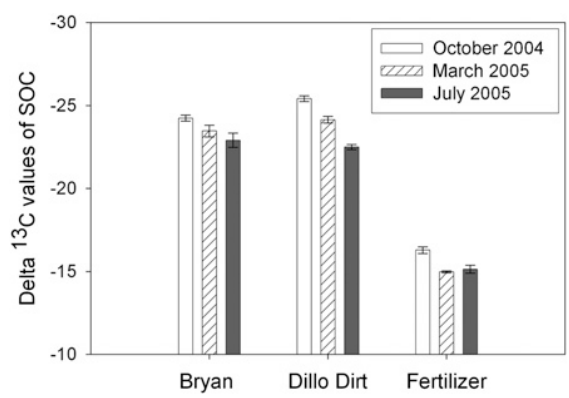

Fig. 1. The Delta ${ }^{13} \mathrm{C}$ values (\% versus V-PDB) of soil organic carbon to a depth of $5 \mathrm{~cm}$ on three sampling dates over 10 months after transplanting Tifway bermudagrass sod from turf grown with inorganic phosphorus fertilizer or composted municipal biosolids from Bryan or Austin (Dillo Dirt), TX. 
Table 3. Percentages of soil organic carbon (SOC) derived from bermudagrass based on isotopic mass balance on three sampling dates.

Sod sources Tifway bermudagrass (\%)

Oct. 2004

\begin{tabular}{ll} 
Bryan CMB & $14 \mathrm{~b}^{\mathrm{z}}$ \\
Dillo Dirt CMB & $12 \mathrm{~b}$ \\
Fertilizer & $82 \mathrm{a}$ \\
ar. 2005 & \\
Bryan CMB & $20 \mathrm{~b}$ \\
Dillo Dirt CMB & $21 \mathrm{~b}$ \\
Fertilizer & $92 \mathrm{a}$ \\
y 2005 & \\
Bryan CMB & $25 \mathrm{c}$ \\
Dillo Dirt CMB & $34 \mathrm{~b}$ \\
Fertilizer & $91 \mathrm{a}$ \\
\hline
\end{tabular}
within columns are not significantly different $(P<$ 0.05 ) for each sampling date.

3). The percentage of SOC derived from turfgrass 10 months after transplanting increased $(P<0.001) 79 \%$ for sod amended with Bryan compost and $183 \%$ for sod amended with Dillo Dirt (Table 3). Increases in both the percentage of SOC derived from turfgrass and SOC storage reflected the net outcome of new $\mathrm{C}$ inputs derived from bermudagrass and simultaneous decomposition and loss of $\mathrm{C}$ derived from both $\mathrm{CMB}$ and bermudagrass (Tables 2 and 3 ). Increases of SOC attributed to turfgrass during the 10 imported with sod increased $\mathrm{C}$ sequestration in turfgrass biomass compared with sod grown with inorganic fertilizer only.

Greater concentrations of total $\mathrm{N}$ and $\mathrm{P}$ and of soil-test $\mathrm{P}$ and $\mathrm{K}$ within the 0 - to $5-\mathrm{cm}$ depth in July 2005 were associated with greater SOC storage in CMB than fertilizergrown sod during 10 months after transplanting (Table 4). Similar increases in soil-test $P$ and $\mathrm{K}$ were reported previously in soils amended with $80 \mathrm{mg}$ of CMB during turfgrass establishment and maintenance over a 29-month period under field conditions (Wright et al., 2007). Fertilizer N (150 $\mathrm{kg} \cdot \mathrm{ha}^{-1} \mathrm{~N}$ ) was applied to each sod source on lysimeters, but greater soil-test concentrations of $\mathrm{P}$ and $\mathrm{K}$ in $\mathrm{CMB}$-grown sod could have increased turfgrass contributions to SOC and $\mathrm{C}$ sequestration compared with fertilizer-grown sod.

Composted municipal biosolid contribution to carbon sequestration. In contrast to the previous report of fluctuating SOC levels after CMB application and seeding of bermudagrass turf (Wright et al., 2005), SOC
SOC derived from

${ }^{\mathrm{z}}$ Means followed by the same lower case letter months after transplanting indicated CMB

increased steadily over 10 months after transplanting of CMB-grown Tifway bermudagrass sod (Table 2). Although SOC increased at a higher rate after transplanting for all three sod sources than was reported previously, SOC increases were greatest for $\mathrm{CMB}$-amended sod. Increasing values of $\delta^{13} \mathrm{C}$ and of the percent of SOC derived from Tifway bermudagrass showed the beneficial effects of $\mathrm{CMB}$ on SOC storage during sod establishment. Those benefits included the CMB sources of nutrients available for turfgrass growth in the present study. Other benefits of CMB amendments include improved soil physical properties (Vietor et al., 2007). Yet, additional research is needed to relate variation of soil physical properties to variation of turfgrass contributions to SOC during sod growth with and without CMB. Previous CENTURY model simulations of turfgrass indicated return of clippings could increase long-term C sequestration up to 25\% (Qian et al., 2003). Yet, similar clipping yields between CMB and fertilizer-grown sod, which equaled $25 \%$ of increases of SOC in the present study, indicated other $\mathrm{C}$ sources contributed to increases in SOC. Bermudagrass biomass and residues below the clipping height were the likely source of short-term increases in SOC storage in the present study. Although CMB amendments increased leaching loss of DOC, losses were small and did not appreciably diminish SOC sequestration.

\section{Conclusion}

Tifway bermudagrass sod produced with CMB contributed to short-term SOC storage and greater rates of SOC deposition after transplanting than was observed for fertilizer-grown sod. Ten months after transplanting and establishment of the Tifway sod, increases in $\delta^{13} \mathrm{C}$ values and turfgrass contributions to SOC were highest for Dillo Dirtamended sod. The Dillo Dirt effects on turfgrass contributions to SOC reflected differences in total $\mathrm{C}, \mathrm{N}$, and $\mathrm{P}$ between $\mathrm{CMB}$ sources used to amend sod and in total and extractable soil nutrient concentrations on the final sampling date. Leaching loss of DOC during seven simulated rain events was similar between sods amended with the two CMB sources, but was two times greater for CMB than fertilizer-grown sod. Despite $\mathrm{CMB}$ contributions to increased storage of SOC, DOC leaching losses from the transplanted sod were comparable to low values reported previously for established grass-

Table 4. Mean total and soil-test nutrient concentrations within 0- to 5-cm depth of box lysimeters on which sods grown with two sources of composted municipal biosolids (CMB) or inorganic fertilizer were transplanted.

\begin{tabular}{|c|c|c|c|c|c|c|}
\hline \multirow[b]{3}{*}{ Sod source } & \multicolumn{3}{|c|}{ Total nutrient concn } & \multicolumn{3}{|c|}{ Soil test concn } \\
\hline & Nitrogen & Phosphorus & Potassium & Nitrogen & Phosphorus & Potassium \\
\hline & --- & - & ------ $(\mathrm{m}$ & $\left.\mathrm{g}^{-1}\right)----$ & & \\
\hline Bryan CMB & $1,425 b^{z}$ & $449 \mathrm{~b}$ & $507 \mathrm{~b}$ & $11.3 \mathrm{a}$ & $168 \mathrm{~b}$ & $77 \mathrm{~b}$ \\
\hline Dillo Dirt CMB & $1,900 \mathrm{a}$ & $854 \mathrm{a}$ & $584 \mathrm{a}$ & $7.8 \mathrm{ab}$ & $285 \mathrm{a}$ & $92 \mathrm{a}$ \\
\hline Fertilizer & $350 \mathrm{c}$ & $90 \mathrm{c}$ & $556 \mathrm{ab}$ & $4.0 \mathrm{~b}$ & $13 \mathrm{c}$ & $62 \mathrm{c}$ \\
\hline
\end{tabular}

${ }^{\mathrm{z}}$ Means followed by the same lower case letter within columns are not significantly different $(P=0.05)$. lands. Cycling CMB through turfgrass sod offers an opportunity to enhance $\mathrm{C}$ sequestration in soils over the short term after sod is transplanted.

\section{Literature Cited}

Bandaranayake, W., Y.L. Qian, W. Parton, D.S Ojima, and R.F. Follet. 2003. Estimation of soil carbon sequestration in turfgrass systems using the CENTURY model. Agron. J. 95:558563.

Bernoux, M., C.C. Cerri, C. Neill, and J.F.L. de Moraes. 1998. The use of stable carbon isotopes for estimating soil organic matter turnover rates. Geoderma 82:43-58.

Boutton, T.W. 1996. Stable carbon isotope ratios of soil organic matter and their use as indicators of vegetation and climate change, p. 47-82. In: Boutton, T.W. and Shinichi Yamasaki (eds.). Mass spectrometry of soils. Marcel Dekker, Inc., New York, NY.

Boutton, T.W., S.A. Archer, and A.J. Midwood. 1999. Stable isotopes in ecosystem science: Structure, function, and dynamics of a subtropical savanna. Rapid Commun. Mass Spectrom. 13:1263-1277.

Boyle, M., W.T. Frankenberger, Jr., and L.H Stolzy. 1989. The influence of organic matter on soil aggregation and water infiltration. J. Prod. Agr. 2:290-299.

Brye, K.R., J.M. Norman, L.G. Bundy, and S.T. Gower. 2001. Nitrogen and carbon leaching in agroecosystems and their role in denitrification potential. J. Environ. Qual. 30:58-70.

Chantigny, M.H. 2003. Dissolved and waterextrractable organic matter in soils: A review on the influence of land use and management practices. Geoderma 113:357-380.

Coplen, T.B. 1995. Discontinuance of SMOW and PDB. Nature 375:285.

Dorich, R.A. and D.W. Nelson. 1984. Evaluation of manual cadmium reduction methods for determination of nitrate in potassium chloride extracts of soils. Soil Sci. Soc. Amer. J. 48:7275.

Fernandes, S.A.P., W. Bettio, and C.C. Cerri. 2005. Sewage sludge effects on gas fluxes at the soilatmosphere interface, on soil delta C-13 and on total soil carbon and nitrogen. Geoderma 125:49-57.

Garling, D.C. and M.J. Boehm. 2001. Temporal effects of compost and fertilizer applications on nitrogen fertility of golf course turfgrass. Agron. J. 93:548-555.

Hansen, N.E., D.M. Vietor, C.L. Munster, R.H. White, and T.L. Provin. 2007. Runoff water quality from turfgrass receiving volume-based composted municipal biosolids applications. J. Environ. Qual. 36:1013-1020.

Hay, F.J., D.M. Vietor, C.L. Munster, R.H. White, and T.L. Provin. 2007. Leaching loss of $\mathrm{NO}_{3}-\mathrm{N}$ and dissolved $\mathrm{P}$ from manure and fertilizer during turfgrass establishment. Plant Soil 296:1-17.

Hut, G. 1987. Consultants' group meeting on stable isotope reference samples for geochemical and hydrological investigations, $42 \mathrm{pp}$. Report to the Director General. International Atomic Energy Agency, Vienna, Austria.

Johnson, G.A., J.G. Davis, Y.L. Qian, and K.C. Doesken. 2006. Topdressing turf with composted manure improves soil quality and protects water quality. Soil Sci. Soc. Amer. J. 70:2114-2121.

Johnson, G.A., Y.L. Qian, and J.G. Davis. 2005. Effects of compost topdressing on turf quality 
and growth of Kentucky bluegrass. Appl. Turfgrass Sci. doi:10.1094/ATS-2006-0113-01-RS.

Keeney, D.R. and D.W. Nelson. 1982. Nitrogeninorganic forms, p. 643-693. In: Page, A.L., R.H. Miller, D.R. Keeney (eds.). Methods of soil analysis. American Society of Agronomy, Madison, WI.

Leavitt, S.W., E.A. Paul, and B.A. Kimball. 1994. Carbon isotope dynamics of free-air $\mathrm{CO}_{2}$ enriched cotton and soils. Agr. For. Meteorol. 70:87-101.

Pouyat, R.V., I.D. Yesilonis, and D.J. Nowak. 2006. Carbon storage by urban soils in the United States. J. Environ. Qual. 35:1566-1575.

Qian, Y.L., W. Bandaranayake, W.J. Parton, B. Mecham, M.A. Harivandi, and A.R. Mosier.
2003. Long-term effects of clipping and nitrogen management in turfgrass on soil organic carbon and nitrogen dynamics: The CENTURY model simulation. J. Environ. Qual. 32:1694-1700.

Royer, I., D.A. Angers, M.H. Chantigny, R.R. Simard, and D. Cluis. 2007. Dissolved organic carbon in runoff and tile-drain water under corn and forage fertilized with hog manure. J. Environ. Qual. 36:855-863.

SAS Institute Inc. 2000. Selected SAS ${ }^{\circledR}$ documentation for Agronomy-Horticulture 595. Agricultural experimentation: Design, analysis, and interpretation. 1st Ed. SAS Institute Inc., Cary, NC.
Vietor, D.M., R.W. Schnell, R.H. White, T.W. Boutton, F.M. Hons, T.L. Provin, C.L. Munster, and X. Dai. 2007. Composted biosolids conserve water, nutrients, and carbon and add value to turfgrass sod. Turfnews 5:5866.

Wright, A.L., T.L. Provin, F.M. Hons, D.A. Zuberer, and R.H. White. 2005. Dissolved organic carbon in soil from compost-amended bermudagrass turf. HortScience 40:830-834.

Wright, A.L., T.L. Provin, F.M. Hons, D.A. Zuberer, and R.H. White. 2007. Nutrient accumulation and availability in compost-amended turfgrass soil. HortScience 42:1473-1477. 